\title{
IMPACT OF HUMAN PERSPECTIVE OF INTELLECTUAL CAPITAL ON TRADE CREDIT WITH MODERATING ROLE OF PROFITABILITY IN PAKISTAN
}

\author{
Asma Masood $^{1 *}$, Muhammad Ayub Siddiqui ${ }^{2}$ \\ ${ }^{1 *, 2}$ FAST-National University of Computer \& Emerging Sciences (NUCES) Islamabad, Pakistan. \\ Email: ${ }^{1 *}$ asmamasood872009@ gmail.com, ${ }^{2}$ ayub.siddiqui@ nu.edu.pk
}

Article History: Received on $15^{\text {th }}$ April 2021, Revised on $25^{\text {th }}$ April 2021, Published on $1^{\text {st }}$ May 2021

\begin{abstract}
Purpose: This paper analyzes the impact that human capital has on trade credit in Pakistan's chemical sector. Human capital is a component of intellectual capital.

Methodology: HC or Human Capital is taken as an independent variable. The dependent variable is trade credit. Trade credit has two types: Trade Credit Used (TCU) and trade credit extended (TCE). Other variables are also used, such as profitability (PROF), short-term bank credit (SBC), financial leverage (LEV). For empirical investigation, balanced panel data is used for the time 2010 to 2019. For obtaining econometric outcomes, we applied the static panel in E-views.
\end{abstract}

Main Findings: The results indicate that short-term bank credit, leverage, and the interaction term of human capital and profitability create a positive impact with the used trade credit and TCE, while the impact of profitability and human credit on trade credit used is negative. Trade credit extended profitability is moderating the relationship of human capital and trade credit.

Implications/Applications: This study has great importance for firm managers, policymakers, investors, academicians, and scholars in the selected sector of Pakistan.

Novelty/Originality of this study: The study recommends the efficient, effective utilization of human capital and trade credit to gain a comparative advantage.

Keywords: Human Capital, Trade Credit, Profitability, Short-term Bank Credit, Leverage, Intellectual Capital.

INTRODUCTION

Trade credit is considered an essential source of finance and is mostly arranged for short-term financing (Huang, Ying, Yang, \& Hassan, 2019). Goods and services are financed by trade credit that is sold in the form of post-pay, so firms can pay on time to fulfill their day-to-day activities (Del Gaudio, Porzio, \& Verdoliva, 2018). Specific terms and conditions apply to trade credits, unlike other sources of finance. The financer can impose penalties on the corporation that does not pay within the permitted period; extra interest is charged.

Trade credit consists of two main elements, i.e., trade credit utilized (TCU) that is accounts payable, and another factor is trade credit extended (TCE) that is accounts receivable. These two are essential types of informal financing (Fisman \& Love, 2003). Firms worldwide utilize trade credit to finance their day-to-day functions for sustainable operations, growth, and development to gain a competitive edge in the market (Lee, Zhou, \& Wang, 2018). Trade credit is used widely by businesses, and some consider it as a better alternative to credit from banks (Pattnaik, Kumar, \& Vashishtha, 2020).

The use of trade credit is high in developing countries. One of the main reasons for this is the underdeveloped financial institutions and stock markets (Liu, Wang, \& Shou, 2020). The above discussion reflects how important is trade credit in corporate financing. The proliferation and importance of trade credit have led corporations to explore the factors that can be considered in developing and implementing practical and effective trade credit policies. However, the importance of trade credit can not be taken for granted for gaining a competitive edge in the market, but trade credit stand-alone cannot assist firms and economies to grow, and there are other factors that directly or indirectly affect trade credit, and eventually, firm growth such as intellectual capital and especially its sub-component; human capital (Love, Preve, \& Sarria-Allende, 2007).

In the 1960s, Theodore Schulz proposed the theory of human capital. Schultz indicated that human productivity increases with more investment in education and training, and eventually, it increases return rates, improving project implementation, better decision-making skills, and success (Engelen, 2015). The resource-based strategic view indicates that a sustainable competitive advantage can be gained if a company cannot imitate or replace the competitor (Burkart \& Ellingsen, 2004).

Human capital management efficiently and effectively can enhance the productivity and innovation rate of the firms (Burkart \& Ellingsen, 2004). In today's competitive environment, most businesses consider investment in intellectual capital as an essential strategic element to survive. Human capital, as mentioned earlier, plays a significant role in a firm's growth and 
profitability. Therefore human capital plays a crucial role in providing a competitive position to firms among other competitors (St-Pierre, Sakka, \& Bahri, 2018).

When we talk about human capital, it is sometimes indirectly created in a firm. However, earlier literature found that social trust created human capital (Wu, Firth, \& Rui, 2014) and improved institutional governance (Wu et al., 2014). Social trust has a major role in creating human and intellectual capital. Therefore, eventually, human capital plays an important role in bringing about and explains the disparities in regional economic and institutional performance (such as governments and large organizations) (Jedinger, 2013).

Previous empirical studies emphasize human capital as the key factor which explains the achievement of an organization's goals (MBEMBE, MUTEGI, \& WERE, 2019). In this regard, highly educated employees can capitalize on their know-how and social connections through education and training to obtain the resources they need to do increase productivity in the long term. Human capital increases with education and training because this process passes on the previous experiences of the organization, thus increasing organizational learning. More targeted training also helps to teach technical skills for specialized jobs (Clark, 2020). Burkart and Ellingsen (2004) suggested that general information about effective skills, knowledge, and abilities is a key factor in determining an organization and a company's prosperity. Human capital theory plays an essential role in linking employee capabilities to the Company's accounts receivable management. Human capital plays a crucial role in the decision policies of firms. As suggested by the human capital theory, more intellectual capital helps in making better decisions in future by making use of more information quickly and effectively. That is why human capital directly or indirectly is playing an important role in decisions related to utilizing or extending trade credit (Y. Zhang, 2020).

Several different factors might influence the association of trade credit and human capital. Profitability is one of that associative factor which may affect the connection of trade credit and human capital. Therefore, profitability may act as a moderator (Chen, Yuan, \& Zhou, 2019).

Many scholars have been actively studying trade credit, emphasizing the importance of and motives behind the use of TCE and TCU. Most of the prior studies investigated the influence of those characteristics, which are the direct determinants of trade credit such as gross profit margin, increase in sales and hence profitability, firm size, stock-in-trade, liquidity, collateral, and leverage (Chung, Cárdenas-Barrón, \& Ting, 2014). According to the literature, none of the previous studies has focused on knowledge-based Facets such as human capital that is an intangible asset, and how these facets directly or indirectly affecting trade credit at the firm level (Z. Zhang, 2019).

\section{The objective of the study}

This study aims at examining the relationship human capital has on trade credit and provides a strong basis through an empirical investigation of facts related to the relationship between human capital and the trade credit chemical sector of Pakistan throughout 2010-2019.

There are some other independent variables whose impact on trade credit is also analyzed, such as profitability, financial leverage, and short-term bank credit. At the same time, profitability is being checked for its moderating role between human capital and trade credit.

This article is organized in the following way: Section 2 presents a review of literature from previous studies. Section 3 represents methodology and data description. Section 4 gives results and discussion. The last section concludes the paper and makes recommendations.

\section{LITERATURE REVIEW}

\section{Trade credit}

Trade credit is an important source of finance (Rajan \& Zingales, 1995), and companies typically use it as an important source of short-term finance (Seifert, Seifert, \& Protopappa-Sieke, 2013). Most of the companies around the world use it extensively to fund their business activities and growth (Maksimovic, 2001). For example, in the UK, more than $80 \%$ of commerce is done through credit (Booth, Aivazian, Demirguc-Kunt, \& Maksimovic, 2001), and similarly in the US, 80\% of companies sell products through credit (Beck, Demirgüç-Kunt, \& Maksimovic, 2008). Paul and Boden (2008) observed that accounts payable accounted for approximately 40 percent of total liabilities reported by US companies. In addition, the average utilization of trade credit by businesses is important in almost every country. For example, in the United States, large companies use accounts payable to meet 15 percent of their funding needs (Ng, Smith, \& Smith, 1999).

Companies provide trade credit to expand businesses through attracting new customers (Cai, Chen, \& Xiao, 2014). It is also used as a marketing tool by companies that offer new products or enter new markets. The Company provides trade credit to establish and keep lasting business relations with customers ( $\mathrm{Ng}$ et al., 1999). Close business relationships with customers 
provide them with better information and monitoring benefits than banks. They can more effectively and quickly assess a customer's financial performance, creditworthiness, and default probability (Delannay \& Weill, 2004).

Niskanen and Niskanen (2006) believed if companies have easy access to capital markets and banks, then they could offer more trade credit. ${ }^{1}$ Delannay and Weill (2004) emphasized that the trade credit provided by a company is greatly influenced by its size, growth, profitability, and leverage. Companies that pay higher debt lending costs offer fewer trade credits (Ahmad, Afza, \& Nafees, 2017), and companies that generate more cash flow from their businesses offer more trade credits (García-Teruel \& Martinez-Solano, 2010). Highly profitable companies with liquid positions offer more trade credit ( $\mathrm{Su}_{2}$ 2012; Vaidya, 2011). It has been found that companies that use more internal funds can provide more trade credit, which helps in transferring liquidity to their clients. Tsuruta (2013) found that companies paying higher interest rate costs and facing liquidity deficits cannot offer higher trade credits to the clients.

The effectiveness of trade credit controlling is imperative in Company's financing strategy because it influences the firm's risk and profitability (Martínez-Sola, García-Teruel, \& Martínez-Solano, 2014). According to Tsuruta (2013), a firm's financial performance (profitability) affects trade credit extended such as better financial performance more trade credit. Latter, Martínez-Sola et al. (2014) also analyzed the impact of profitability on trade credit extended and found identical results. Whereas in the case of trade credit used, suppliers provide trade credit to those firms, which have a better financial position (Ahmad \& Afza, 2018).

Prior literature related to trade credit has explored trade credit's connection with different variables such as monetary policy, financial distress, bank credit, sales growth, profitability, culture, ethnicity, and leverage (Ahmad et al., 2017). Several researchers have aggressively explored trade credit since the mid of the twentieth century. They have emphasized numerous motives and elements of extended trade credit and used trade credit by corporations. However, no one emphasized how the knowledge (intellectual capital) of a firm influences the trade credit, which still needs to be investigated.

In addition to the above determinants of trade credit, previous studies have shown that a company's trade credit practices are also affected by macroeconomic factors, knowledge base capital, and company-specific characteristics. For example, Hasan and Habib (2019) have an explanation for social capital (knowledge-based capital) impact on trade credit in the united states. Nevertheless, there is no study, which copes with analyzing the effects of other elements of intellectual such as human capital.

\section{Human capital}

The literature divides intellectual capital into three parts: human, relational, and structural capital (Bontis, Bart, \& Serenko, 2009). Our study focuses on one of the components of intellectual capital, which is human capital. Theodore Schultz proposed the theory of human capital in the 1960s. Schultz believes that skills and knowledge are a kind of capital, which is the product of intentional organizational growth (Tan, 2014). The concept of human capital means investing in people through education and training. Schultz compared the acquisition of knowledge and skills with the acquisition of production materials. Schultz believes that investment in education and training can increase human productivity, increase positive rates of return, and help make appropriate decisions for the firms, thereby improving project implementation and success (Korpi \& Clark, 2015).

Human capital is the source of innovation for all ladders and the home page of insights (Nowak \& Grantham, 2000). Becker (1992) said that investing in humans is like investing in physical capital because it is impossible to separate knowledge, skills, and values from one person, but said it would be human capital produced by the Company. Human capital depends to some extent on its employees' talent (Haslinda \& Sarinah, 2009). The Company does not permanently own this capital. When an employee leaves the organization, so does the capital. Therefore, we can conclude that human capital consists of all the default knowledge built into the Company.

The organization's human capital incorporates aptitudes, mastery, capacities, critical thinking abilities, and initiative style(Blair \& Kochan, 2002). Prior literature determined a correlation between human capital and economic growth decision making, policy making, sales growth, profitability, leverage (Diebolt \& Hippe, 2019).

Previous literature has shown several mechanisms by which social confidence influences economic growth, including the creation of human capital (Schuller, 2001).To improve the quality of organizational governance and increase investment or transactions (Burton-Jones \& Spender, 2012). Granting and receiving trade credit is an important type of informal loan (Aguinis, Gottfredson, \& Joo, 2012). This is an area where trust seems to be necessary. Therefore, most studies analyze the impact of social trust on the trade credit that companies receive and provide. Whereas still there is lacking literature where the direct impact of human capital on trade credit still needs to be addressed.

${ }^{1}$ Brennan, Maksimovics, and Zechner reported similar findings (1988) 
The organization's survival, growth, and sustainability depend on more knowledge resources than in goods manufacturing. However, human capital is one of the knowledge-based assets that firms need for strategic attention. Therefore, a clear estimation of the costs; has gained significant importance as it may directly or indirectly influence the profitability (Olowolaju \& Oluwasesin, 2016). Based on past evidence in this study, we hypothesize that either human capital with or without profitability is affecting trade credit.

\section{Theoretical framework}

To explain the objective of the present research, the following schematic diagram of the dependent, independent, and moderating variables have been made below to explain how the variables link together;

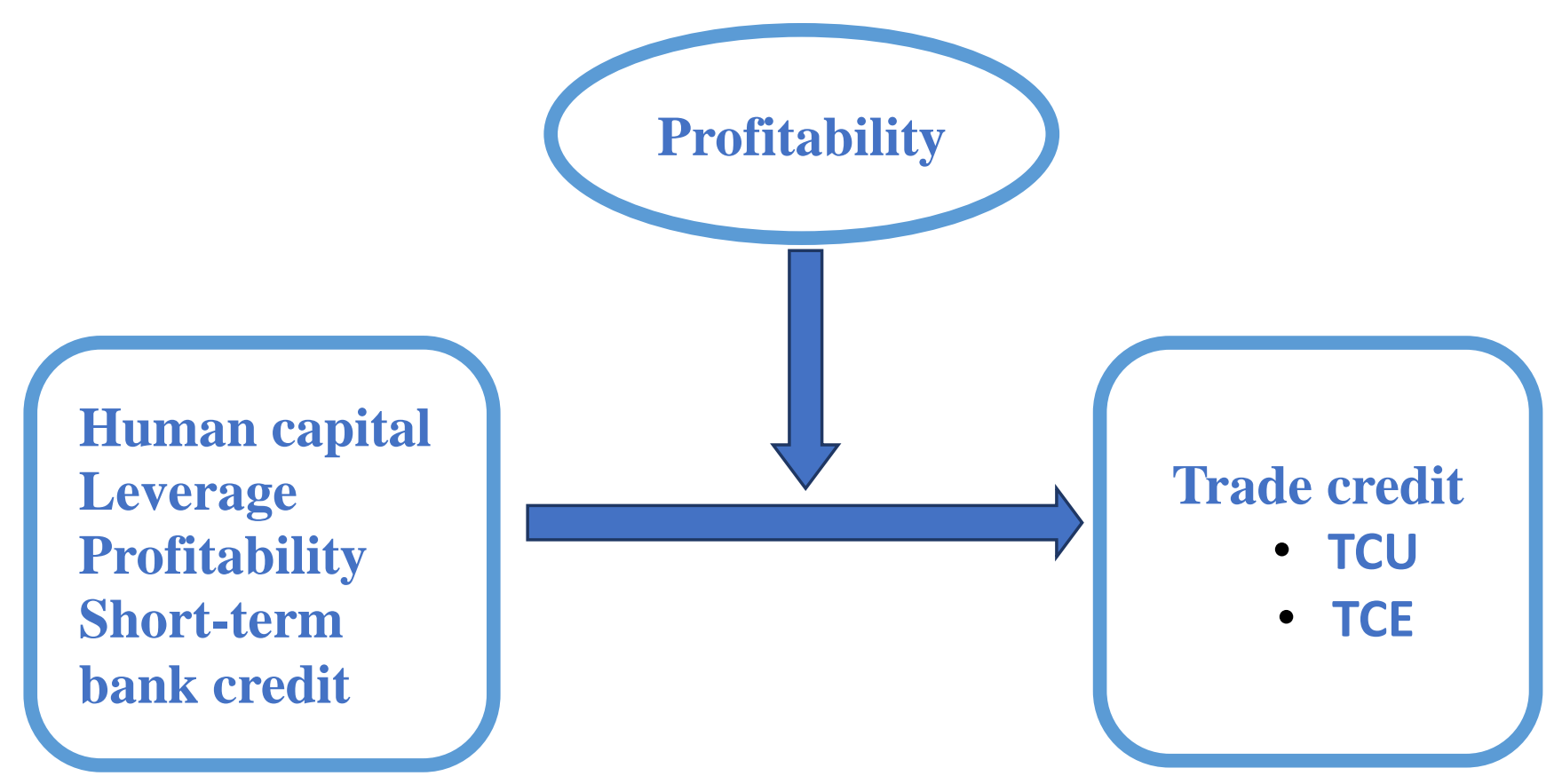

Figure 1: Theoretical diagram

Source: Author

\section{METHODOLOGY}

This research is based on the chemical sector of Pakistan. The firms registered simultaneously from 2010 to 2019 are being considered the sample of this research. Data is collected from a secondary source such as the Thomson router. Balanced panel data is employed to fulfill the objectives and motives of the study. There are certain positives of panel data, such as the co-linearity issue is reduced between the variables, and it is more efficient and informative (Kumari \& Sharma, 2017).

\section{Operationalization of variable}

Table 1: Description of Variables

\begin{tabular}{rlccl}
\hline & Variable & Abbreviation & Proxies & \multicolumn{1}{c}{ Operationalization } \\
\hline 1. & Trade Credit Extended & TEC & Ratio & Trade receivables/total assets \\
\hline 2. & Trade Credit Utilized & TCU & Ratio & Trade payable/EBIT \\
\hline 3. & Human Capital & HC & $\begin{array}{c}\text { Net Income per employee } \\
\text { ratio }\end{array}$ & Net income/no of employees \\
\hline 4. & Financial leverage & LEV & Debt equity ratio & Total debt/total equity \\
\hline 5. & Profitability & PROF & Operating profit ratio & $\begin{array}{l}\text { (Operating profit+depreciation) } \\
\text { /sales }\end{array}$ \\
\hline 6. & Short term bank credit & SBC & $\begin{array}{c}\text { Firm use short term bank } \\
\text { credit }\end{array}$ & Short term bank borrowings/sales \\
\hline
\end{tabular}




\section{Model selection and estimation}

To analyze the effects of independent and control variables on trade credit, it is better to employ the panel data technique. Trade credit used (TCU) is the first of the two kinds of trade credit. Therefore, a model for dependent, independent, and the moderator is given below:

$$
\begin{aligned}
& \mathrm{TCE}_{\mathrm{it}}=\beta_{0}+\beta_{1} \mathrm{HC}_{\mathrm{it}}+\beta_{2} \mathrm{LEV}_{\mathrm{it}}+\beta_{3} \mathrm{PROF}_{\mathrm{it}}+\beta_{4} \mathrm{SBC}_{\mathrm{it}}+\beta_{5} \mathrm{HC} * \mathrm{PROF}_{\mathrm{it}}+\mu_{\mathrm{it}} \\
& \mathrm{TCU}_{\mathrm{it}}=\beta_{0}+\beta_{1} \mathrm{HC}_{\mathrm{it}}+\beta_{2} \mathrm{LEV}_{\mathrm{it}}+\beta_{3} \mathrm{PROF}_{\mathrm{it}}+\beta_{4} \mathrm{SBC}_{\mathrm{it}}+\beta_{5} \mathrm{HC} * \mathrm{PROF}_{\mathrm{it}}+\mu_{\mathrm{it}}
\end{aligned}
$$

In the panel model technique, the most commonly used models are the fixed-effect model \& random effect model (ChaseLansdale et al., 2019). For choosing the best of the two models, we check the value of the Hausman test. According to (Gujarati, Porter, \& Gunasekar, 2012), if the statistical probability value of the Hausman test is less than 5 percent, then it is feasible to use a fixed-effect model. For better empirical analysis, the random effect model is more appropriate, as shown by the Hausman test.

\section{Variable construction}

\section{Trade Credit Extended}

TCE is simply calculated as the ratio of total trade debtors, i.e., the closing balance of trade debtors divided by total sales revenue. This is the amount of credit extended by you to any business as part of your business terms and conditions. Kwenda and Matanda (2015), in line with the preceding analysis directed by (Partha \& Nagaraja, 2015) the study used the trade debtto-sales magnitude relation associate agent for firms to increase trade credit to consumers.

\section{Trade Credit Utilized}

Trade credit used is the amount of credit any company extends to you as part of your business terms and conditions. It is calculated as the ratio of total trade creditors, i.e., the closing balance of trade creditors divided by total sales revenue.

\section{Human Capital}

Human capital represents the generation of total sales revenue and net income by utilizing the workforce. The proxy of human capital is the income ratio.

\section{Short-term bank credit (SBC)}

Companies that have the right of entry to bank credit can give additional trade credit to consumers with monetary constraints. Yusuf (2013) noticed that banks are the top providers of credit, then organizations with a bigger capacity to lift funds from monetary mediators will allocate credit to consumers. United Nations agencies are financially affected via trade credit. Later, Ghosh (2015) recognized the very fact that the trade credits and bank credits extended by Indian organizations are completely related and determined at the same time. According to the previous analysis, the supply of short bank credit to the corporate is dignified by the magnitude relation of outstanding short bank credit to sales. The next magnitude relation implies that the corporate will use additional short bank credit and contrariwise.

Companies that get a lot of short-run bank credit from monetary intercessors needless trade credit and assume that bank credit will replace trade credit. As an alternative, firms will use a mix of funding rather than wishing on one supply of funding. Supplementary assumptions and signal theory additionally support the simultaneous use of both sources, i.e. trade credit and short-run bank credit (Andrieu, Staglianò, \& Van Der Zwan, 2018). Ghosh (2015) believes that trade credit and bank credit square measure complementary and there square measure few alternatives. Just like (Giannetti, Burkart, \& Ellingsen, 2011; Park, Ruiz, \& Tressel, 2015; Vaidya, 2011), this study uses short-run bank credit to sales magnitude relation to switch the short-run bank credit out there to organizations.

\section{Profitability}

According to finance motivation, a high-margin corporation's area unit generating extra cash ensures operations; therefore, liquidity is transferred to customers by commerce merchandise on credit. Conversely, corporations with low profits in bother cannot enforce payment of assets as a result of they rely upon their enduring consumers. Previous researches (Pessanha, de Alcântara, Calegario, dos Santos, \& de Ázara, 2014), the Company's operational ratio is dignified by shrewd the magnitude relation of operational revenue (before devaluation) to sales.

\section{Financial Leverage}

The proxy used for financial leverage in this study is debt to equity studies (Morris, 2016; Xu, Chen, \& Zheng, 2016). Previous studies depict that when firms have a higher debt ratio, then their probability of default is more so suppliers and banks become hesitant to give these firms credit. 


\section{RESULTS AND ANALYSIS}

\section{Descriptive stats}

Descriptive statistics findings are shown in the table below. The findings of the descriptive statistics demonstrate that the mean value of the trade credit used and extended are 0.4888 and 0.0970 , while the maximum values are 14.48 and 0.6768 and minimum values are -24.95 and 3.6700, respectively. Findings of the descriptive statistics indicate that the mean values of profitability, human capital, short-term bank credit, and leverage are $0.1854,0.0143,0.2213$, and 0.8604 , respectively.

Table 2: Descriptive stats

\begin{tabular}{lclllll}
\hline & TCU & TCE & \multicolumn{1}{c}{ PROF } & HC SBC & LEV \\
\hline Mean & 0.48 & 0.097 & 0.18 & 0.01 & 0.22 & 0.86 \\
\hline Median & 0.35 & 0.058 & 0.15 & 0.004 & 0.18 & 0.62 \\
\hline Maximum & 14.48 & 0.67 & 0.69 & 0.13 & 0.73 & 7.56 \\
\hline Minimum & -24.95 & $3.67 \mathrm{E}-06-0.10$ & -0.01 & 0.00 & 0.00 \\
\hline Std. Dev. & 2.32 & 0.10 & 0.11 & 0.02 & 0.16 & 0.89 \\
\hline Skewness & -3.47 & 2.39 & 1.08 & 2.22 & 0.77 & 2.84 \\
\hline Kurtosis & 70.72 & 11.03 & 5.01 & 9.30 & 2.98 & 17.09 \\
\hline Jarque-Bera & 47510.53 & 898.28 & 89.55 & 611.1 & 24.48 & 2367.9 \\
\hline Probability & 0.00 & 0.00 & 0.00 & 0.00 & 0.00 & 0.00 \\
\hline
\end{tabular}

\section{Correlation matrix}

Correlation results are presented in the table below. The findings indicated that there is a positive correlation between shortterm bank credit and leverage while the a negative relationship between profitability and human capital in listed chemical companies in Pakistan. Further, the findings of the trade credit extended to indicate a positive relationship with profitability, human capital, short-term bank credit, and leverage, respectively, in listed chemical companies in the Pakistan stock exchange.

Table 3: Correlation matrix

\begin{tabular}{lcccccc}
\hline & TCU & TCE & PROF & HC & SBC & LEV \\
\hline TCU & 1.00 & & & & & \\
\hline TCE & 0.03 & 1.00 & & & & \\
\hline PROF & -0.06 & 0.16 & 1.00 & & & \\
\hline HC & -0.06 & 0.08 & 0.73 & 1.00 & & \\
\hline SBC & 0.10 & 0.03 & -0.37 & -0.34 & 1.00 & \\
\hline LEV & 0.12 & 0.03 & -0.40 & -0.36 & 0.60 & 1.00 \\
\hline
\end{tabular}

\section{Trade credit used}

Among the firm level, indicators profitability human capital (HC), (prof), short-term bank credit (SBC), financial leverage (LEV), and the interaction term of human capital and profitability (HC*Prof) are all statistically significant. Profitability and human capital have a strong negative link with trade credit used (TCU), while the rest are positive. Further, profitability significantly impacts the level of trade credit used. The coefficient of profitability -2.14 is significant at 0.05 level. Statistical findings reveal that bank credit is easily accessible to firms with higher profitability; therefore, chances of using trade credit become less likely. The findings indicate that $1 \%$ increase in profitability negatively influences the trade credit used and causes to decrease by about 2.14 percent (all other factors constant). The negative connection between profitability and trade credit used is in line with the results of (Al Dohaiman, 2013; Delannay \& Weill, 2004; Kwenda \& Holden, 2014; Niskanen \& Niskanen, 2006).

The coefficient of short-term bank credit (SBC) 0.36 is significant at 5\% level of significance. The positive connection between short-term bank credit (SBC) and trade credit used (TCU) demonstrates that they both complement each other. One percent increase in short-term bank credit positively affects the trade credit used and helps to increase it by about 0.36 percent per year (all other factors constant). Instead of using a single source of financing, firms prefer to use a mixture of both short-term bank credit and trade credit. Previous studies also revile that some firms use trade credit and short-term bank credit interchangeably. The results of this study are consistent with (Bougheas, Mateut, \& Mizen, 2009; Ghosh, 2015; Petersen \& Rajan, 1997).

The positive and significant association between financial leverage (LEV) and trade credit used (TCU) can be confirmed by its statistical coefficient, which is 0.14 at $5 \%$ level of significance. Findings demonstrate that one percent increase in 
leverage helps to increase the trade credit used by about 0.14 percent per year in Pakistan. The examined findings contradict the following researchers. (García-Teruel \& Martinez-Solano, 2010) pointed out the negative relationship between trade credit and long-term finance. Another study done by Kwenda and Holden (2014) found no evidence of a correlation between trade credit and long-term fiancé. Based on the profitability of the hypothesis, financial leverage and trade credit has the following expected relationship. The examined results of panel EGLS (estimated generalized least squares) indicate that human capital has a negative and significant impact on the trade credit used in Pakistani chemical sector companies for the time period from 2010 to 2019. Findings of the panel EGLS indicates that one percent increase in human capital causes to decrease in the trade credit used by about 10.85 percent in chemical sector listed in the Pakistan stock exchange. The organization's human capital incorporates aptitudes, mastery, capacities, critical thinking abilities, and initiative style (Brooking, Board, \& Jones, 1998). Prior literature determined a correlation between human capital and economic growth decision making, policy making, sales growth, profitability, leverage (Diebolt \& Hippe, 2019; Ghanbari \& Ghasemi, 2015; Jahanzeb \& Bajuri, 2014; Olowolaju \& Oluwasesin, 2016) .

Additionally, in this study, we checked the interaction of human capital and profitability. The findings of human capital and profitability interaction indicate a positive and significant impact on the trade credit used in the chemical sector listed companies in the Pakistan stock exchange for the years 2010 to 2019. Examined findings indicate that a one percent increase in human capital and profitability interaction positively impacts the trade credit used and boosts it about 27.30 percent in chemical sector listed companies.

The last section of the panel EGLS (estimated generalized least squares) demonstrates descriptive statistics. The examined results of R-square indicate that 65 percent variation in the trade credit used is explained by profitability, leverage, human capital, and short-term bank credit, while the remaining 35 percent variation is caused by other factors that are not part of this study. Results of the F-statistic indicate that the used model is fit and has no problem.

Table 4: TCU Results

\begin{tabular}{lll}
\hline \multicolumn{3}{l}{ Dependent } \\
\hline Variable & Coefficient & t statistic \\
\hline Constant & 0.72 & $6.17^{* *}$ \\
\hline Prof & -2.14 & $-5.09^{* *}$ \\
\hline SBC & 0.36 & $2.43^{* *}$ \\
\hline LEV & 0.14 & $2.60^{* *}$ \\
\hline HC & -10.85 & $-3.94^{* *}$ \\
\hline HC*Prof & 27.30 & $4.76^{* *}$ \\
\hline R Square: 0.65 & \\
Adj. R Square: 0.57 & \\
F Stat: $8.41(0.000)^{* *}$ \\
Hausman Stat: $7.6(0.001)^{* *}$ \\
D.W Stat :1.90 \\
\hline ** show 5 percent level of significance. \\
\hline
\end{tabular}

\section{Trade credit extended}

Among the firm level, indicators profitability (prof), short-term bank credit (SBC), financial leverage (LEV), human capital (HC), the interaction term of human capital, and profitability (HC*Prof) are all statistically significant. Profitability and human capital have a strong negative link with trade credit used (TCE), while the rest are positive. The findings of the panel EGLS indicate that profitability has a non-significant negative impact on the trade credit extended in chemical sector companies listed in the Pakistan stock exchange for the time period 2010 to 2019 . The findings demonstrate that a 1 percent increase in profitability causes a decrease in the trade credit extended about 0.028 percent in chemical sector listed companies in the Pakistan stock exchange. The statistical value of the profitability coefficient is negative and not significant at 5 percent level of significance. The negative value of the profitability coefficient suggests a substitution effect between trade credit extended and operating cash flow. The results of this study are consistent with Petersen and Rajan (1997). Burkart and Ellingsen (2004), made a suggestion that firms that are in financial hardships extend more trade credit for the stability of their sales. Outcomes of the research are not in accordance with the liquidity motive. ${ }^{2}$

The findings of the panel EGLS indicate that short-term bank credit positively and significantly influences the trade credit extended in the listed chemical companies. The examined findings indicate an increase in short-term bank credit for day-today business activities has a positive impact on the trade credit extended and boosts it about 0.019 percent in the listed

${ }^{2}$ Profitable firms with more internal cash flow transfer liquidity to their customers through trade credit. 
chemical sector companies in Pakistan. (Andrieu et al., 2018),(Ghosh, 2015)established that trade credit and bank credits are more complements and less substitute for each other. Similar to (Gibilaro \& Mattarocci, 2011; Vaidya, 2011; Yang, 2011), the short-term bank credit to sales ratio is used in this study as a proxy for the availability of short-term bank credit to firms.

The investigated results of leverage indicate a positive and significant impact on the trade credit extended in listed chemical sector companies in Pakistan. The findings of this study indicate that a one percent increase in leverage increases 0.004 percent per year in Pakistan. These findings of the study are consistent with (Tsuruta, 2013). Human capital findings indicate a negative and significant impact on the trade credit extended in chemical companies listed in the Pakistan stock exchange from 2010 to 2019. Results indicate that a one percent increase in human capital causes to decrease in the trade credit used by about 0.77 percent per year. Compared to formal education, more targeted employee training can provide employees with specific knowledge (Korpi \& Clark, 2015). Tan (2014) suggested that general information about compelling skills, knowledge, and abilities is a key factor in determining the prosperity of an organization and Company.

Further, this study used the interaction term of human capital with profitability to enhance the effect of human capital on the trade credit extended in chemical companies listed in the Pakistan stock exchange. The findings show one percent increase in the interaction term of human capital and profitability causes a positive impact on the trade credit extended and boosts it by about 2.66 percent in Pakistani listed chemical sector companies.

The last portion of the results indicates that 96 percent variations in the trade credit extended are explained by the used independent variables, while the remaining 4 percent is caused by other external elements that are not used in this study. Findings of the F-statistic indicate that the used model is fit and has no problem in estimation. The examined results of the Durbin-Watson statistic indicate that no problem of autocorrelation exists in the used model.

Table 5: TCE Results

\begin{tabular}{lll}
\hline \multicolumn{3}{l}{ Dependent Variable: TCE } \\
\hline Variable & Coefficient & t statistic \\
\hline Constant & 0.093692 & $19.59^{* *}$ \\
\hline Prof & -0.028308 & $-1.24^{* *}$ \\
\hline SBC & 0.019130 & $2.06^{* *}$ \\
\hline LEV & 0.004449 & $1.75^{* *}$ \\
\hline HC & -0.773192 & $-3.61^{* *}$ \\
\hline HC*Prof & 2.662879 & $4.11^{* *}$ \\
\hline R Square: 0.96 \\
Adj. R Square: 0.96 \\
F Stat: 143.65 $(0.000)^{* *}$ \\
Hausman Stat: $6.7(0.001)^{* *}$ \\
D.W Stat :1.71 \\
\hline ** show 5 percent level of significance. \\
\hline
\end{tabular}

\section{CONCLUSION AND RECOMMENDATIONS}

The present work's main purpose was to identify the impact of human capital, leverage, profitability, and short-term bank credit on trade credit in the chemical sector of Pakistan. It is explained by the results that trade credit can be influenced by human capital, leverage, profitability, and short term bank credit., this paper seeks to identify that how human capital is influencing trade credit in the chemical sector of Pakistan, covering a time span from 2010 to 2019 and taking top 100 companies on the basis of market capitalization. Data analysis is carried out with descriptive statistics, correlation matrix, and EGLS.

The examined results of the panel EGLS indicate that short-term bank credit, leverage, and the interaction term of human capital and profitability have a positive impact on the trade credit used, while profitability and human capital have a negative impact on the trade credit used and trade credit extended.

Based on the examined results of this study, it is observed that chemical sector companies listed in the Pakistan stock exchange are playing a very important role in promoting the trade credit in Pakistan. It is noted that the chemical sector have reduced credit redistribution due to financial development and credit information sharing in Pakistan. It suggests that customers of chemical sector companies listed in the Pakistan stock exchange have reduced their demand for trade credit while suppliers increased the supply of trade credit due to depth of financial market, enhancements of financial institutions, information sharing about credit, and rates of lending. It is recommended that management of the chemical sector listed companies in Pakistan stock exchange should revise their traditional trade credit policies caused by the improvement in the sharing information about credit and financial development. The negative relationship of the human capital and trade credit 
in the listed chemical sector companies with financial development requires the financial policymakers for listed firms in Pakistan should encourage the management to invest in human capital. This is to enhance the scope of the trade credit for credit allocation in all sectors of Pakistan's economy.

\section{LIMITATION AND FUTURE STUDY}

In this article, we have focused on the human perspective of intellectual capital on trade credit used and extended, whereas we could not consider all the components of intellectual capital impact on trade credit due to time and data constraints. Therefore, in the future, all the components of intellectual capital can be considered.

\section{STATEMENT OF COMPETING INTEREST}

This statement is to certify that the authors of this research hereby declare no competing interests regarding this article's publication.

\section{AUTHOR CONTRIBUTION}

Asma Masood does the write-up of the thesis, whereas Dr. Ayub Siddiqui does the analysis part of the article. Every author has a significant contribution to this article.

\section{ACKNOWLEDGEMENT}

We would like to thank all the independent reviewers of HSSR who conducted a feasibility study of our research work.

\section{REFERENCES}

1. Aguinis, H., Gottfredson, R. K., \& Joo, H. (2012). Delivering effective performance feedback: The strengths-based approach. Business Horizons, 55(2), 105-111. https://doi.org/10.1016/j.bushor.2011.10.004

2. Ahmad, N., \& Afza, T. (2018). Determinants Of Trade Credit Financing: Case Of Manufacturing Firms Listed In Pakistan. Pakistan Business Review, 20(1), 110-121.

3. Ahmad, N., Afza, T., \& Nafees, B. (2017). Determinants of trade credit extended by manufacturing firms listed in Pakistan. Business \& Economic Review, 9(4), 287-314. https://doi.org/10.22547/BER/9.4.13

4. Al Dohaiman, M. S. (2013). Explaining the determinants of trade credit: An empirical study in the case of Saudi Arabian's unlisted Firms. Research Journal of Finance and Accounting, 4(17), 204-212.

5. Andrieu, G., Staglianò, R., \& Van Der Zwan, P. (2018). Bank debt and trade credit for SMEs in Europe: firm-, industry-, and country-level determinants. Small Business Economics, 51(1), 245-264. https://doi.org/10.100 7/s11187-017-9926-y

6. Beck, T., Demirgüç-Kunt, A., \& Maksimovic, V. (2008). Financing patterns around the world: Are small firms different? Journal of financial economics, 89(3), 467-487. https://doi.org/10.1016/j.jfineco.2007.10.005

7. Becker, G. S. (1992). Human capital and the economy. Proceedings of the American philosophical society, 136(1), 85-92.

8. Blair, M. M., \& Kochan, T. A. (2002). The new relationship: Human capital in the American corporation: Brookings institution press.

9. Bontis, N., Bart, C., \& Serenko, A. (2009). A causal model of human capital antecedents and consequents in the financial services industry. Journal of intellectual capital, 10(1), 53-69. https://doi.org/10.1108/146 91930910922897

10. Booth, L., Aivazian, V., Demirguc-Kunt, A., \& Maksimovic, V. (2001). Capital structures in developing countries. The Journal of Finance, 56(1), 87-130. https://doi.org/10.1111/0022-1082.00320

11. Bougheas, S., Mateut, S., \& Mizen, P. (2009). Corporate trade credit and inventories: New evidence of a trade-off from accounts payable and receivable. Journal of Banking \& Finance, 33(2), 300-307. https://doi.org/10.1016/j.jbankfin.2008.07.019

12. Brooking, A., Board, P., \& Jones, S. (1998). The predictive potential of intellectual capital. International Journal of Technology Management, 16(1-3), 115-125. https://doi.org/10.1504/IJTM.1998.002646

13. Burkart, M., \& Ellingsen, T. (2004). In-kind finance: A theory of trade credit. American economic review, 94(3), 569-590. https://doi.org/10.1257/0002828041464579

14. Burton-Jones, A., \& Spender, J.-C. (2012). The Oxford handbook of human capital: OUP Oxford. https://doi.org/10.1093/oxfordhb/9780199532162.001.0001

15. Cai, G., Chen, X., \& Xiao, Z. (2014). The roles of bank and trade credits: Theoretical analysis and empirical evidence. Production and Operations Management, 23(4), 583-598. https://doi.org/10.1111/poms.12035

16. Chase-Lansdale, P. L., Sabol, T. J., Sommer, T. E., Chor, E., Cooperman, A. W., Brooks-Gunn, J., . . Morris, A. (2019). Effects of a two-generation human capital program on low-income parents' education, employment, and psychological wellbeing. Journal of Family Psychology, 33(4), 433. https://doi.org/10.1037/fam0000517 
17. Chen, Z., Yuan, K., \& Zhou, S. (2019). Supply chain coordination with trade credit under the CVaR criterion. International Journal of Production Research, 57(11), 3538-3553. https://doi.org/10.1080/00207543.2018.1543966

18. Chung, K.-J., Cárdenas-Barrón, L. E., \& Ting, P.-S. (2014). An inventory model with the non-instantaneous receipt and exponentially deteriorating items for an integrated three-layer supply chain system under two levels of trade credit. International Journal of Production Economics, 155, 310-317. https://doi.org/10.1016/j.ijpe.2013.12.033

19. Clark, R. (2020). Income inequality in the post-2000 era: Development, globalization, and the state. International Sociology, 35(3), 260-283. https://doi.org/10.1177/0268580920905464

20. Del Gaudio, B. L., Porzio, C., \& Verdoliva, V. (2018). Trade credit, SMEs and short-run survivorship: what we know and what we would like to know. Qualitative Research in Financial Markets,10(4), 346-362. https://doi.org/10.1108/QRFM-02-2018-0014

21. Delannay, A.-F., \& Weill, L. (2004). The determinants of trade credit in transition countries.Economics of Planning, 37(3-4), 173-193. https://doi.org/10.1007/s10644-005-5062-9

22. Diebolt, C., \& Hippe, R. (2019). The long-run impact of human capital on innovation and economic development in the regions of Europe. Applied Economics, 51(5), 542-563. https://doi.org/10.1080/00036846.2018.1495820

23. Engelen, E. (2015). Don't mind the 'funding gap': what Dutch post-crisis storytelling tells us about elite politics in financialized capitalism. Environment and Planning A: Economy and Space, 47(8), 1606-1623. https://doi.org/ $10.1068 / \mathrm{a} 130227 \mathrm{p}$

24. Fisman, R., \& Love, I. (2003). Trade credit, financial intermediary development, and industry growth. The Journal of finance, 58(1), 353-374. https://doi.org/10.1111/1540-6261.00527

25. García-Teruel, P. J., \& Martinez-Solano, P. (2010). Determinants of trade credit: A comparative study of European SMEs. International Small Business Journal, 28(3), 215-233. https://doi.org/10.1177/0266242609360603

26. Ghanbari, M., \& Ghasemi, M. (2015). The impact of human capital on sales growth and assets return among the companies listed in Tehran Stock Exchange. European Online Journal of Natural and Social Sciences: Proceedings, 4(1 (s)), pp. 724-731.

27. Ghosh, A. (2015). Banking-industry specific and regional economic determinants of non-performing loans: Evidence from US states. Journal of financial stability, 20, 93-104. https://doi.org/10.1016/j.jfs.2015.08.004

28. Giannetti, M., Burkart, M., \& Ellingsen, T. (2011). What you sell is what you lend? Explaining trade credit contracts. The review of financial studies, 24(4), 1261-1298. https://doi.org/10.1093/rfs/hhn096

29. Gibilaro, L., \& Mattarocci, G. (2011). Interaction between trade credit and debt: Evidence from the Italian market. International Business \& Economics Research Journal (IBER), 10(3), 103-112. https://doi.org/10.19030/i ber.v10i3.4106

30. Gujarati, D. N., Porter, D. C., \& Gunasekar, S. (2012). Basic econometrics: Tata McGraw-Hill Education.

31. Hasan, M. M., \& Habib, A. (2019). Social capital and trade credit. International Review of Financial Analysis, 61, 158-174. https://doi.org/10.1016/j.irfa.2018.10.002

32. Haslinda, A., \& Sarinah, A. (2009). A review of knowledge management models. Journal of international social research, 2(9),187-198.

33. Huang, L., Ying, Q., Yang, S., \& Hassan, H. (2019). Trade Credit Financing and Sustainable Growth of Firms: Empirical Evidence from China. Sustainability, 11(4), 1032. https://doi.org/10.3390/su11041032

34. Jahanzeb, A., \& Bajuri, N. H. (2014). Determinants of Capital Structure and Human Capital. International Journal of Information Processing and Management, 5(4), 114.

35. Jedinger, S. (2013). Making Capitalism Work. Empirische Befunde zum Einfluss von Sozialkapital auf Wirtschaftswachstum. Politische Vierteljahresschrift, 337-362. https://doi.org/10.5771/0032-3470-2013-2-337

36. Korpi, M., \& Clark, W. A. (2015). Internal migration and human capital theory: To what extent is it selective? Economics Letters, 136, 31-34. https://doi.org/10.1016/j.econlet.2015.08.016

37. Kumari, R., \& Sharma, A. K. (2017). Determinants of foreign direct investment in developing countries: a panel data study. International Journal of Emerging Markets 12(4), 658-682

38. Kwenda, F., \& Holden, M. (2014). Trade credit in corporate financing in South Africa: evidence from a dynamic panel data analysis. Investment management and financial innovations(11, Iss. 4 (cont.)), 268-278.

39. Kwenda, F., \& Matanda, E. (2015). Working capital management in the liquidity-constrained economy: a case of Zimbabwe stock exchange-listed firms in the multiple currency era. Public and Municipal Finance, 4(1), 55-65.

40. Lee, H.-H., Zhou, J., \& Wang, J. (2018). Trade credit financing under competition and its impact on firm performance in supply chains. Manufacturing \& Service Operations Management, 20(1), 36-52. https://doi.org/10.1287/msom.2017.0640

41. Liu, B., Wang, Y., \& Shou, Y. (2020). Trade credit in emerging economies: an inter-organizational power perspective. Industrial Management \& Data Systems,120(4),768-783. https://doi.org/10.1108/IMDS-05-2019-0292

42. Love, I., Preve, L. A., \& Sarria-Allende, V. (2007). Trade credit and bank credit: Evidence from recent financial crises. Journal of Financial Economics, 83(2), 453-469. https://doi.org/10.1016/j.jfineco.2005.11.002 
43. Maksimovic, V. (2001). Firms as financial intermediaries: Evidence from trade credit data: The World Bank. https://doi.org/10.1596/1813-9450-2696

44. Martínez-Sola, C., García-Teruel, P. J., \& Martínez-Solano, P. (2014). Trade credit and SME profitability. Small Business Economics, 42(3), 561-577. https://doi.org/10.1007/s11187-013-9491-y

45. MBEMBE, S. M., MUTEGI, D., \& WERE, E. (2019). Factors Affecting Accounts Receivables Management: A Case Study Of Selected Pharmaceutical Distributors In Nairobi County. International Journal of Business Management and Finance, 1(1), 347-368.

46. Morris, S. A. (2016). Direct lineage reprogramming via pioneer factors; a detour through developmental gene regulatory networks. Development, 143(15), 2696-2705. https://doi.org/10.1242/dev.138263

47. Ng, C. K., Smith, J. K., \& Smith, R. L. (1999). Evidence on the determinants of credit terms used in interfirm trade. The journal of finance, 54(3), 1109-1129. https://doi.org/10.1111/0022-1082.00138

48. Niskanen, J., \& Niskanen, M. (2006). The determinants of corporate trade credit policies in a bank-dominated financial environment: The case of Finnish small firms. European Financial Management, 12(1), 81-102. https://doi.org/10.1111/j.1354-7798.2006.00311.x

49. Nowak, M. J., \& Grantham, C. E. (2000). The virtual incubator: managing human capital in the software industry. Research Policy, 29(2), 125-134. https://doi.org/10.1016/S0048-7333(99)00054-2

50. Olowolaju, P. S., \& Oluwasesin, O. D. (2016). Effect of Human Capital Expenditure on the Profitability of Quoted Manufacturing Companies in Nigeria. Asian Journal of Finance \& Accounting, 8(2), 347-389. https://doi.org/10.52 96/ajfa.v8i2.10197

51. Park, H., Ruiz, C., \& Tressel, T. (2015). Determinants of long-term versus short-term bank credit in EU countries: The World Bank. https://doi.org/10.1596/1813-9450-7436

52. Partha, T., \& Nagaraja, N. (2015). The Small Scale Industries and Finance: New Approaches. International Journal of Engineering and Management Research (IJEMR), 5(1), 290-294.

53. Pattnaik, D., Kumar, S., \& Vashishtha, A. (2020). Research on trade credit-a systematic review and bibliometric analysis. Qualitative Research in Financial Markets,12(4),367-390. https://doi.org/10.1108/QRFM-09-2019-0103

54. Paul, S., \& Boden, R. (2008). The secret life of UK trade credit supply: setting a new research agenda. The British Accounting Review, 40(3), 272-281.

55. Pessanha, G., de Alcântara, J., Calegario, C., dos Santos, A., \& de Ázara, L. (2014). Influence of Foreign Direct Investments (FDI) in the profitability and risk: an application of time series models, from 2000 to 2012, in a food sector company. Organizações Rurais e Agroindustriais, 16(4), 481-495.

56. Petersen, M. A., \& Rajan, R. G. (1997). Trade credit: theories and evidence. The review of financial studies, 10(3), 661-691. https://doi.org/10.1093/rfs/10.3.661

57. Rajan, R. G., \& Zingales, L. (1995). What do we know about capital structure? Some evidence from international data. The Journal of Finance, 50(5), 1421-1460. https://doi.org/10.1111/j.1540-6261.1995.tb05184.x

58. Schuller, T. (2001). The complementary roles of human and social capital. Canadian Journal of Policy Research, 2(1), 18-24.

59. Seifert, D., Seifert, R. W., \& Protopappa-Sieke, M. (2013). Trade credit: literature review and research directions. European Journal of Operational Research, 231(ARTICLE), 245-256. https://doi.org/10.1016/j.ejor.2013.03.016

60. St-Pierre, J., Sakka, O., \& Bahri, M. (2018). External financing, export intensity and inter-organizational collaborations: Evidence from Canadian SMEs. Journal of Small Business Management, 56, 68-87. https://doi.org/10.1111/jsbm. 12390

61. Su, C.-H. (2012). Optimal replenishment policy for an integrated inventory system with defective items and allowable shortage under trade credit. International Journal of Production Economics, 139(1), 247-256. https://doi.org/10.1016/j.ijpe.2012.05.001

62. Tan, E. (2014). Human capital theory: A holistic criticism. Review of Educational Research, 84(3), 411-445. https://doi.org/10.3102/0034654314532696

63. Tsuruta, D. (2013). Credit Contagion and Trade Credit: Evidence from Small Business Data in J apan. Asian Economic Journal, 27(4), 341-367. https://doi.org/10.1111/asej.12018

64. Vaidya, R. R. (2011). The determinants of trade credit: Evidence from Indian manufacturing firms. Modern Economy, 2(05), 707. https://doi.org/10.4236/me.2011.25079

65. Wu, W., Firth, M., \& Rui, O. M. (2014). Trust and the provision of trade credit. Journal of Banking \& Finance, 39, 146-159. https://doi.org/10.1016/j.jbankfin.2013.11.019

66. Xu, Y., Chen, G., \& Zheng, J. (2016). An integrated solution-KAGFM for mass customization in customeroriented product design under cloud manufacturing environment. The International Journal of Advanced Manufacturing Technology, 84(1-4), 85-101. https://doi.org/10.1007/s00170-015-8074-2

67. Yang, X. (2011). Trade credit versus bank credit: Evidence from corporate inventory financing. The Quarterly Review of Economics and Finance, 51(4), 419-434. https://doi.org/10.1016/j.qref.2011.07.001 
68. Yusuf, I. (2013). The relationship between human capital efficiency and financial performance: An empirical investigation of quoted Nigerian banks. Research Journal of Finance and Accounting, ISSN, 2222-1697. https://doi.org/10.1016/j.jaccpubpol.2020.106728

69. Zhang, Y. (2020). Conditional conservatism and trade credit during the global financial crisis. Journal of Accounting and Public Policy, 39(4), 106728. https://doi.org/10.1017/S0022109018001163

70. Zhang, Z. (2019). Bank interventions and trade credit: evidence from debt covenant violations. Journal of Financial and Quantitative Analysis, 54(5), 2179-2207. 